\title{
Influence of Some Process Parameters on Defined Characteristics of Sorghum Beer during Very High Gravity Fermentation
}

\author{
O. H. Raji ${ }^{1}$, A. A. Onilude ${ }^{2}$ and O. O. Olorode ${ }^{1}$ \\ I(Department of Food Technology, Moshood Abiola Polytechnic, Ogun State, Nigeria) \\ ${ }^{2}$ (Department of Microbiology, University of Ibadan, Ibadan, Oyo State, Nigeria)
}

\begin{abstract}
This study was carried out to investigate the influence of some process parameters on defined characteristics of sorghum beer during very high gravity fermentation. The yeast (Saccharomyces uvarum)was pitched in very High Gravity Wort from two varieties (red and white) of sorghum (Sorghum bicolor). Changes in some process parameters like $\mathrm{pH}$, specific gravity, percentage alcohol by volume, free amino nitrogen, total reducing sugar, total nitrogen and total protein were investigated over a period of 5 days of fermentation. Results showed that $\mathrm{pH}$ values decreased as fermentation proceeded with increased total acidity while alcohol contents of the fermenting wort increased from the first day to the fifth day of fermentation. There were observed decrease in specific gravity, total reducing sugar, free amino nitrogen (FAN), Percentage total nitrogen and Percentage total protein from first day to the fifth day of fermentation. The red sorghum had a lower $\mathrm{pH}$, higher specific gravity and alcohol content than the white sorghum. This showed that Saccharomyces uvarum can grow well in very high gravity sorghum wort and $\mathrm{pH}$, specific gravity, free alpha amino nitrogen is an important aspect of the wort for yeast fermentation.
\end{abstract}

Keywords: High gravity fermentatiom, sorghum, wort, yeast

\section{Introduction}

Worldwide the brewing industry is becoming more competitive and is constantly looking for ways to improve beer quality and reduce manufacturing costs. Beer is one of the world's oldest and most widely consumed alcoholic beverage[1]; it is the third most popular drink overall after water and tea[2]. Barley malt and brewing adjuncts are a main factor contributing to overall production costs; thus, the utilization of alternative raw materials and innovative processes can increase profitability. Sorghum is a leading contender for replacing barley malt in beer production, particularly in tropical countries where barley cultivation is unsuccessful. Saccharomyces uvarum is, under most conditions, a poorly sporogenous yeast most commonly used in the production of alcoholic beverages and vitamin assays[3]. It is also known as lager yeast, bottomfermenting yeast and has a history of safe use.

Fermentation is the process of deriving energy from the oxidation of organic compounds, such as carbohydrates using an endogenous electron acceptor, which is usually an organic compound[4]. In brewing, alcoholic fermentation is the conversion of sugar into carbondioxide gas $\left(\mathrm{CO}_{2}\right)$ and ethyl alcohol. This process is carried out by yeast enzymes, the cell gained energy from the breakdown of sugar. Wort is the liquid extracted from the mashing process during the brewing of beer or whisky. High gravity brewing is a technique that allows the brewing of a larger end-batch volume without buying larger fermentation equipment and it can be described as a procedure which employs wort at higher than normal extract[5].There are a number of advantages associated with high-gravity brewing. It results in beers that are more consistent (\% alcohol, original gravity, etc.) and more physically stable. The disadvantages are longer fermentation times, different flavor characteristics, and poorer hop utilization than normal gravity fermentations[6] .

Sorghum malt has been used for the fermentation of high-gravity beer. However, sorghum in contrast to barley has less diastatic, amylase and glucanase activities and requires a higher temperature for starch gelatinization[7,8,9]. Thus, when sorghum malt is used, starch may not be sufficiently hydrolyzed causing difficulties during wort filtration and beer haziness. This study is aimed at isolating and identifying Saccharomyces uvarum from fresh brewery flocs and investigating the influence of some process parameters on defined characteristics of sorghum beer during very high gravity fermentation.

\subsection{Samples Collection}

\section{Materials And Methods}

Sorghum samples made up of two local varieties, red and white were purchased from Bodija market in Oyo State, Nigeria. Their selection was based on colour difference. Floc sample containing the brewer's yeast was obtained from Nigerian Breweries Factory in Ibadan, Nigeria. The floc sample was collected in a sample bottle containing 5\% (w/v) D-glucose, transported to the laboratory and stored in the refrigerator until analysis commenced. 


\subsection{Isolation Procedure}

The floc sample was serially diluted in 10-fold dilutions[10]. Higher dilutions were plated on yeast extract dextrose agar and incubated at $28^{\circ} \mathrm{C}$ for 3-5 days. Pure cultures were obtained using streaking method by sub-culturing distinct colonies onto same medium earlier used for the isolation. The pure cultures were stored on a slant and preserved in the refrigerator.

\subsection{Identification Procedure}

The procedures employed in the identification process were as described by Van Der Walt and Yarrow [11]. They involved study of morphological as well as physiological and biochemical characterization.

\subsubsection{Morphological Characterization}

Morphological characteristics of the cultures such as shape, cellular dimension and type of cell division were observed by microscopic analysis of the strains. A smear of the isolate was made on a clean glass slide using lactophenol cotton blue stain. The stained isolates were covered with cover slips and observed under the light microscope viewed at objective $\mathrm{x} 100$. The shape and budding structure of each isolate was observed and noted. Pseudomycelium formation was carried out according to the method of Clark[12].

\subsubsection{Biochemical and Physiological Characterization}

\subsubsection{Catalase Test}

The isolates were tested for catalase production by making a smear in 3\% hydrogen peroxide. Production of effervescence indicates a positive result.

\subsubsection{Carbohydrate Fermentation}

This was carried out according to the method of Wickerham[13]. Sugars used include: glucose, galactose, lactose, fructose, melibiose, raffinose, sorbitol, maltose, sucrose.

\subsubsection{Urease Test}

This was assayed using Christensen medium.The slants were inoculated and incubated at $25^{\circ} \mathrm{C}$ for 5 days. A change from yellow to pink indicates positive results.

\subsubsection{Acid Production from Glucose}

The yeast isolates were tested for the production of acid from glucose in a medium consisting of 5\% glucose and $0.5 \%$ calcium carbonate[11]

\subsubsection{Gelatin Liquefaction}

It was carried out according to the method of Van Der Walt and Yarrow[11]

\subsubsection{Growth on 50\% Glucose-Yeast Extract Agar}

The ability of the isolates to grow on high concentrations of sugar was tested by growth on yeast extract agar media containing $50 \%(\mathrm{w} / \mathrm{v})$ glucose[11]

\subsubsection{Growth at $37^{\circ} \mathrm{C}$}

The yeast isolates were grown on yeast extract agar enriched with glucose and incubated at $37^{\circ} \mathrm{C}$ at $3-5$ days. Visible Growth on plates indicate positive test.

\subsection{Wort Production}

\subsubsection{Preparation of Sorghum Malt}

Sorghum was malted according to the method of Del Pozo- Insfran[14]. Sorghum malts were milled at the Chemistry Laboratory of The Nigerian Institute of Science Laboratory Technology, Samonda, Ibadan with Hammer Mill of $10 \mu \mathrm{m}$ sieve size. The ground malts were stored in polythene bags pending further use.

\subsubsection{Proximate Analysis of Malted and Unmalted Sorghum Samples}

Proximate analysis was performed on $30 \mathrm{~g}$ of whole kernel unmalted and maltedsorghum samples to measure dry matter using AOAC Method 990.03, crude fat using AOAC Method 390.15, crude proteinusing AOAC method 920.39, and ash using AOAC Method 942.05[15] 


\subsubsection{Wort Preparation}

Triple decoction process, according to the method of Goldammer[16] was used in preparing $30 \%(\mathrm{w} / \mathrm{v})$ of the grounded malt.The adjunct (corn) was separately mixed and added to the wort at a ratio of 1:4 $\mathrm{g}$ after steaming for 5 minutes in boiling water bath[17] before separating the liquid extract from the spent wort using muslin cloth. Thereafter, the wort was boiled and the timer set for 60 minutes and hops was added to impart bitterness and aroma.

\subsection{Inoculum Development and Size}

$1 \%(\mathrm{v} / \mathrm{v})$ of Saccharomyces uvarum cells were cultured in $20 \mathrm{ml}$ of YM broth $(0.3 \%$ yeast extract, $0.3 \%$ malt extract, $0.5 \%$ peptone and $1.0 \%$ glucose), and incubated at $25^{\circ} \mathrm{C}$. Samples were routinely taken every four hours and the number of cells present per ml of broth was determined using a Neubauer Hemocytometer.The inoculum size was determined by using a Neubauer counting chamber $(0.1 \mathrm{mn}$ depth). Yeast cells were harvested from the 16-hour broth culture by centrifugation. Cells were then suspended in $10 \mathrm{mls}$ of sterile deionized water. $1 \mathrm{ml}$ of the cell suspension was introduced into dry surface-sterilized counting chamber using a sterile syringe and viewed under the $x 10$ objective of a light microscope. The number of cells within the square boxes of the chamber was counted and their average was determined to obtain the inoculum size of the organism.

\subsection{Pitching of Yeast in Wort Medium}

The prepared wort was inoculated with $1 \mathrm{ml}$ of pre-determined inoculum size of the cell suspension of test organism. It was incubated for 5 days at $25^{\circ} \mathrm{C}$.

\subsection{Analysis}

2.7.1 pH Measurement

A pHep pocket-sized pH meter (Hanna HI 7007, Hanna Instruments,Woonsocket, RI 02895) was used for the measurement of the $\mathrm{pH}$ of the wort at the pre-fermentative and the post-fermentative stage. Approximately $25 \mathrm{~mL}$ of wort were placed into a $50 \mathrm{~mL}$ beaker. The probe was inserted into the liquid and gently stirred until a stable $\mathrm{pH}$ was displayed.

\subsubsection{Specific Gravity Determination}

The Specific Gravity method of Pearson was used[18].

\subsubsection{Percentage Alcohol by Volume}

Percentage Alcohol by volume was determined using the method of Papazain[19]

\subsubsection{Total Reducing Sugar}

The total reducing sugar was determined according to dinitrosalicyclic assay method of Bernfield[20]. The Optical Density (O.D) of the solution was measured using JENWAY 6405 ultraviolet/visible spectrophotometer at 540nm. Known volume of maltose was treated as stated above and the volumes obtained were plotted to make a standard curve from which the reducing power of sugar was extrapolated.

\subsubsection{Free Amino Nitrogen (FAN)}

Free Amino Nitrogen was determined using the ninhydrin assay method as prescribed by the European Brewery convention method 8.8.1[21].

\subsubsection{Percentage Total Nitrogen} kjeldahl method.

Percentage total nitrogen was determined using block digestion and steam distillation according to

\subsubsection{Percentage Total Protein} $6.25[22]$

Percentage total protein was determined using the method of Hough i.e. percentage total nitrogen $x$

\section{Result And Discussion}

The results of the morphological, physiological and biochemical reactions of the eight isolated yeast cultures are presented in Table 1a and 1b. The eight cultures were all classified as Sacchromyces uvarum strains. Saccharomyces species: are catalase positive, urease negative, produce acid from glucose and negative to gelatin liquefaction, positive to growth at 50\% glucose. They ferment various sugars with Saccharomyces uvarum fermenting melibiose. They appear creamy white and are motile. Figure 1 shows the growth of Saccharomyces uvarum isolates in yeast extract dextrose medium after 48 hours. It could be observed that isolate (S.uvarum 
NB) 18 had the highest growth with the highest absorbance which is 1.503 compared to isolate NB 3 with the lowest absorbance of 0.967 and as such S.uvarum code 18 was used for the fermentation of the red and white sorghum wort.

TABLE 1a Morphological, physiological and biochemical reactions of the eight isolated yeast cultures

\begin{tabular}{|c|c|c|c|c|c|c|c|}
\hline 1solate's & pigmentation Form & Texture Microscopy & $\begin{array}{l}\text { Catalase } \\
\text { Test }\end{array}$ & $\begin{array}{c}\text { Urease } \\
\text { Test }\end{array}$ & $\begin{array}{l}\text { Acid } \\
\text { Production } \\
\text { From } \\
\text { Glucose }\end{array}$ & $\begin{array}{l}\text { Gelatin } \\
\text { liquefaction }\end{array}$ & $\begin{array}{c}\text { Growth at } \\
50 \% \\
\text { Glucose }\end{array}$ \\
\hline NB 9 & cream glistening & $\begin{array}{l}\text { mucoid ova motile } \\
\text { Budding cells }\end{array}$ & + & - & + & - & + \\
\hline NB 15 & glistening & $\begin{array}{l}\text { mucoid ova motile } \\
\text { Budding cells }\end{array}$ & + & - & + & - & + \\
\hline NB 16 & glistening & $\begin{array}{l}\text { mucoid ova motile } \\
\text { Budding cells }\end{array}$ & + & - & + & - & + \\
\hline NB 18 & glistening & $\begin{array}{l}\text { mucoid ova motile } \\
\text { Budding cells }\end{array}$ & + & - & + & - & + \\
\hline
\end{tabular}

TABLE 1b Sugar fermentation tests of yeast isolates obtained from fresh brewery flocs

\begin{tabular}{|c|c|c|c|c|c|c|c|c|c|c|}
\hline $\begin{array}{l}\text { Isolate's } \\
\text { code }\end{array}$ & $\begin{array}{l}\text { Gluco } \\
\text { se }\end{array}$ & $\begin{array}{l}\text { Galacto } \\
\text { se }\end{array}$ & $\begin{array}{l}\text { Fructos } \\
\text { e }\end{array}$ & Lactose & Maltose & $\begin{array}{l}\text { Mellibios } \\
\text { e }\end{array}$ & Sucrose & Sorbitol & $\begin{array}{l}\text { Raffin } \\
\text { ose }\end{array}$ & Organism \\
\hline NB 3 & + & + & + & - & + & + & + & - & + & S. uvarum \\
\hline NB 9 & + & + & + & - & + & + & + & - & + & S. uvarum \\
\hline NB 13 & + & + & + & - & + & + & + & - & + & S. uvarum \\
\hline NB 15 & + & + & + & - & + & + & + & - & + & S. uvarum \\
\hline NB 16 & + & + & + & - & + & - & + & - & + & S. pombe- \\
\hline NB 20 & + & + & + & - & + & + & + & - & + & S. uvarum \\
\hline NB 23 & + & + & + & - & + & + & + & - & + & S. uvarum \\
\hline
\end{tabular}

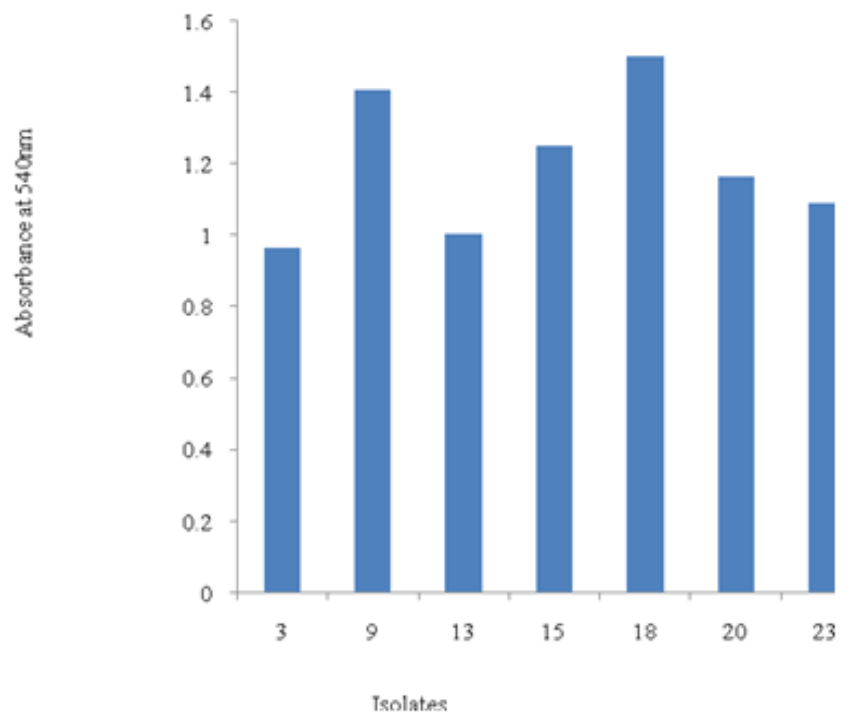

The growth of Saccharomyces uvarum isolates in yeast extract dextrose medium after 48 hours 
TABLE 2 Proximate analysis for both malted and unmalted sorghum samples

\begin{tabular}{|c|c|c|c|c|c|c|}
\hline \multicolumn{2}{|c|}{$\begin{array}{l}\text { Sorghum } \\
\text { Hybrid }\end{array}$} & $\begin{array}{l}\text { Dry }^{\mathrm{a}} \\
\text { Matter (\%) }\end{array}$ & $\begin{array}{c}\text { Protein }^{b} \\
(\%)\end{array}$ & $\begin{array}{l}\text { Fat } \\
(\%)\end{array}$ & $\begin{array}{l}\text { Ash } \\
(\%)\end{array}$ & $\begin{array}{l}\text { Crude Fibre } \\
(\%)\end{array}$ \\
\hline \multirow[t]{2}{*}{ SR } & Umalted & 89.87 & 11.20 & 2.93 & 1.60 & 3.43 \\
\hline & Malted & 90.20 & 10.73 & 2.63 & 1.32 & 3.20 \\
\hline \multirow[t]{2}{*}{ SW } & Unmalted & 90.17 & 10.30 & 3.13 & 1.66 & 3.30 \\
\hline & Malted & 90.40 & 10.00 & 2.87 & 1.35 & 3.03 \\
\hline
\end{tabular}

TABLE 3 Pre-fermentative analysis of wort

\begin{tabular}{lll}
\hline Parameters & Sorghum Variety & \\
& SR & SW \\
\hline $\mathrm{pH}$ & 5.6 & 5.7 \\
Specific Gravity & 1.069 & 1.056 \\
Total Reducing Sugar $(\mathrm{mg} / \mathrm{ml})$ & 1.8130 & 1.6482 \\
Percentage Total Nitrogen & 0.247 & 0.330 \\
Percentage Total Protein & 1.544 & 2.063 \\
Free Amino Nitrogen $(\mathrm{mg} / \mathrm{litre})$ & 69.14 & 142.24 \\
\hline
\end{tabular}

Table 4a Observed changes in parameters of red sorghum (SR) and white sorgum (SW) wort at different

\begin{tabular}{|c|c|c|c|c|c|c|}
\hline $\begin{array}{c}\text { Days of } \\
\text { Fermentation }\end{array}$ & $\begin{array}{c}\text { Sorghum } \\
\text { Variety }\end{array}$ & $\overline{\mathrm{pH}}$ & Specific Gravity & $\begin{array}{c}\% \text { Total } \\
\text { Nitrogen }\end{array}$ & $\%$ Total Protein & $\begin{array}{c}\text { Total Reducing } \\
\text { Sugar }\end{array}$ \\
\hline 1 & SW & $4.45 \pm 0.05$ & $1.034 \pm 0.002$ & $0.207 \pm 0.014$ & $1.294 \pm 0.088$ & $1.193 \pm 0.079$ \\
\hline \multirow[t]{2}{*}{2} & SR & $4.20 \pm 0.00$ & $1.025 \pm 0.002$ & $0.133 \pm 0.002$ & $0.832 \pm 0.007$ & $1.090 \pm 0.039$ \\
\hline & SW & $4.40 \pm 0.00$ & $1.025 \pm 0.001$ & $0.175 \pm 0.008$ & $1.091 \pm 0.047$ & $0.915 \pm 0.039$ \\
\hline \multirow[t]{2}{*}{4} & SR & $3.99 \pm 0.02$ & $0.996 \pm 0.010$ & $0.129 \pm 0.003$ & $0.807 \pm 0.019$ & $0.642 \pm 0.026$ \\
\hline & SW & $4.20 \pm 0.01$ & $0.985 \pm 0.015$ & $0.143 \pm 0.012$ & $0.894 \pm 0.075$ & $0.554 \pm 0.005$ \\
\hline \multirow[t]{2}{*}{5} & SR & $3.92 \pm 0.04$ & $0.982 \pm 0.004$ & $0.122 \pm 0.003$ & $0.763 \pm 0.019$ & $0.302 \pm 0.009$ \\
\hline & SW & $4.16 \pm 0.02$ & $0.976 \pm 0.006$ & $0.133 \pm 0.004$ & $0.831 \pm 0.025$ & $0.457 \pm 0.031$ \\
\hline
\end{tabular}

Table 4b Observed changes in parameters of red sorghum (SR) and white sorgum (SW) wort at different

\begin{tabular}{cccc}
\hline Days of Fermentation & $\begin{array}{c}\text { Sorghum } \\
\text { Variety }\end{array}$ & \% Alcohol & $\begin{array}{c}\text { Free Amino } \\
\text { Nitrogen (mg/l) }\end{array}$ \\
\hline $\mathbf{1}$ & SR & $3.609 \pm 0.066$ & $43.45 \pm 2.59$ \\
& SW & $2.888 \pm 0.263$ & $79.74 \pm 0.09$ \\
$\mathbf{2}$ & SR & $5.841 \pm 0.197$ & $39.22 \pm 0.26$ \\
& SW & $4.069 \pm 0.131$ & $77.67 \pm 1.12$ \\
& SR & $8.269 \pm 1.050$ & $36.03 \pm 1.72$ \\
& SW & $6.694 \pm 0.394$ & $69.22 \pm 0.09$ \\
& SR & $9.582 \pm 0.612$ & $32.33 \pm 3.95$ \\
& SW & $9.319 \pm 1.133$ & $63.10 \pm 1.03$ \\
& SR & $11.419 \pm 0.525$ & $24.48 \pm 0.17$ \\
\hline
\end{tabular}

Sorghum seeds of two varieties (red and white) were subjected to malting, kilning and mashing processes to obtain the wort. The worts obtained were raised to high dextrose level to obtain high gravity wort. It is into each of these that Saccharomyces uvarum was pitched and different parameters studied at the prefermentative and fermentative stage of the wort. Table 2 shows the proximate analysis for both malted and unmalted sorghum samples. Proximate analysis measures the percentage of dry matter, protein, crude fat, crude fibre and ash. The data from proximate analysis in this study was used as a tool to evaluate the changes in the sorghum varieties (red and white) before and after malting. Aisien and Ghosh evaluated a red sorghum from South Africa and white sorghums from Nigeria and Australia, and found the percent protein ranged from 10.3$12.7 \%$, percent fat ranges from $3.0-3.7 \%$, with the red variety containing more fat[23]. This is at variance with the findings in this study as the percent fat of the white sorghum variety is higher than that of the red variety while the percent protein of the red sorghum variety is higher than that of the white variety. The protein, dry matter, fat, crude fibre and ash content for both red and white sorghum found in this study were in the expected ranges. During the course of this study, red sorghum exhibited a higher malting loss over that of white sorghum. 
Table 3 shows the $\mathrm{pH}$, specific gravity, total reducing sugar, percentage total nitrogen, percentage total protein and free amino nitrogen of red (SR) and white (SW) sorghum wort. The $\mathrm{pH}$ for red sorghum wort and white sorghum wort is 5.6 and 5.7 respectively. The specific gravity for SR wort and SW wort is 1.069 and 1.056 respectively. Total reducing sugar in SR and SW wort is $1.8130 \mathrm{mg} / \mathrm{ml}$ and $1.6482 \mathrm{mg} / \mathrm{ml} \mathrm{respectively,}$ percentage total nitrogen for SR and SW is 0.247 and 0.330 respectively, percentage total protein for SR and SW wort is 1.544 and 2.063 respectively, free amino nitrogen in SR and SW wort is $69.14 \mathrm{mg} / \mathrm{litre}$ and 142.24 $\mathrm{mg} / \mathrm{litre}$ respectively. It was observed from this study that there was no significant difference with respect to specific gravity and $\mathrm{pH}$, for both red and white sorghum wort samples. The wort $\mathrm{pH}$ of both red and white sorghum in this study was within the expected range of 5.2-5.8.

Changes in $\mathrm{pH}$, specific gravity, \% total nitrogen, \% total protein and total reducing sugar with fermentation time can be seen in Table 4a for both red (SR) and white sorghum (SW) respectively. At the first day of fermentation SR gave a mean $\mathrm{pH}$ value of $4.25 \pm 0.05$, there was a gradual decrease from the first day to the fifth day of fermentation with a mean $\mathrm{pH}$ value of $3.92 \pm 0.04$. While $\mathrm{SW}$ gave a mean $\mathrm{pH}$ value of $4.45 \pm 0.05$ at the first day decreasing gradually to give a mean $\mathrm{pH}$ value of $4.16 \pm 0.02$ at the fifth day of fermentation. Also it shows the changes in specific gravity values of SR and SW during fermentation. At the first day the specific gravity of SR gave a mean value of $1.042 \pm 0.001$ it decreased gradually to $0.996 \pm 0.01$ at the fourth day, and at the fifth day it gave a mean value of $0.982 \pm 0.004$. For $S W$ the specific gravity gave a mean value of $1.034 \pm 0.002$ at the first day decreasing to $0.976 \pm 0.006$ at the fifth day. Changes in specific gravity and $\mathrm{pH}$ from the wort to the beer obtained in this study indicated fermentation occurred and sugars were consumed. Although white sorghum tends to be a better variety for brewing beer, it was however, observed in this study that red sorghum gave the lowest $\mathrm{pH}$ value indicating a more acidic environment thus a higher alcohol content than white sorghum.

The industry standard for determination of wort and beer nitrogen content has always been the Kjeldahl nitrogen analysis. Nitrogen compounds in worts are fundamental for brewing processes, beer quality and stability. In this study there was observed a decrease in the nitrogen content of both red and white sorghum during fermentation. In red sorghum (SR) wort the percentage total nitrogen during fermentation gave a mean value of $0.151 \pm 0.013 \%$ at the first day with a decrease to $0.122 \pm 0.003 \%$ at the fifth day of fermentation. The percentage total nitrogen of white sorghum (SW) wort during fermentation gave a mean value of $0.207 \pm 0.014 \%$ at the first dayto $0.133 \pm 0.004 \%$ at the fifth day. The overall process from wort to beer showed a significant decrease in nitrogen compounds. It was observed from this study that the protein content of the white sorghum wort was higher than that of the red sorghum and the protein content decreased as the fermentation days proceeded. Wort generally is made up of mainly soluble sugars such as glucose, maltotriose, maltose, fructose, sucrose. These sugars were utilized as carbon and energy sources by yeasts during the fermentation as sugar must be consumed by yeast in order for alcohol to be produced. So, sugars consumption rate is related to yeast cells concentration. The total reducing sugar for both red and white sorghum decreased from the first day of fermentation to the fifth day indicating fermentation occurred. This is in accordance to the work of Reilly who demonstrated that, the rate of sugar utilization increases exponentially for the first 20 hours, with a concomitant increase in yeast cell and ethanol production[24]. Though, total reducing sugar represents the amount of fermentable sugar in beer, the reducing sugar still comprises of certain sugars such as dextrin, trisaccharides and pentosens which are not fermentable by normal brewer's yeast. For high gravity fermentation the yeast cell concentrations increased because there was available nutrient in form of the sugar needed for their growth. Owuama reports that a high level of FAN in wort is necessary to support rapid and proper fermentation[25]. In this study it was observed that a significant difference was found for FAN content of the worts as the white sorghum wort had a higher FAN content than the red sorghum indicating different malts released different amounts of FAN into the worts. The decrease in the FAN level of both red and white sorghum during fermentation indicates that nitrogen was utilized by the yeast and fermentation occurred. The FAN levels found in this study were below and within the range reported by Igyor which is 91-177 mg/L[26]. Table 4b shows the free amino nitrogen content of both red and white sorghum wort during fermentation. For red sorghum (SR) there was observed a decrease from $43.45 \pm 2.59 \mathrm{mg} / \mathrm{L}$ at the first day to $24.48 \pm 0.17 \mathrm{mg} / \mathrm{L}$ at the fifth day. The free amino nitrogen content of white sorghum (SW) wort during fermentation gave a mean value of $79.74 \pm 0.09 \mathrm{mg} / \mathrm{L}$ at the first day with a decrease as the fermentation days proceed with a mean value of $52.07 \pm 0.17 \mathrm{mg} / \mathrm{L}$ at the fifth day. Though the FAN content for red sorghum found in this study was relatively lower than the white sorghum however, these results show that fermentation of red sorghum worts containing as little as $69.14 \mathrm{mg} /$ litre FAN attenuate fully. The alcoholic content of beer is usually regarded as a measure of its strength[27]. The level of alcohol produced during the course of fermentation in this study shows the fermentative performance of the yeast in a high gravity brew environment. Changes in percentage alcohol by volume with fermentation time can be seen in Table $4 \mathrm{~b}$. The percentage alcohol by volume of red sorghum wort (SR) during fermentation gave a mean value of $3.61 \pm 0.07 \%$ at the first day it increased to $11.42 \pm 0.53 \%$ at the fifth day. The percentage alcohol by volume of white sorghum wort (SW) during fermentation gave a mean 
value of $2.89 \pm 0.26 \%$ at the first day, it increased gradually to $6.69 \pm 0.39 \%$ at the third day and a sharp increase was observed at the fifth day of fermentation with a mean value of $10.5 \pm 0.79 \%$. Based on the higher alcohol content produced by the red sorghum, it can be said that perhaps the component of the wort (sugars, peptides, amino acids etc) are easily fermentable by the yeast. Also this could be based on the higher level of the specific gravity of the red sorghum wort (1.069) which indicates more fermentable dissolved solids enabling the yeast to strive more. However, high alcohol content could be detrimental to the yeast as it becomes toxicated in the presence of high alcohol. The alcohol content of both red and white sorghum beer found in this study was not as high as the alcoholic content of most high gravity beers indicating that increasing the nutrient availability of the brewing yeast remains the most likely option to producing beer with a high alcoholic content.

\section{Conclusion}

This study has shown that Saccharomyces uvarum is able to grow in very high gravity sorghum wort. Proximate analysis of the grain provides information for the malting process and can predict the success of malting. $\mathrm{pH}$, specific gravity, free $\alpha$-amino nitrogen (FAN) was an important aspect of the wort for yeast fermentation as the measurement of FAN in both the malt and the wort is important to indicate if successful fermentation may occur. The red sorghum gave the highest alcohol content and the lowest $\mathrm{pH}$ value indicating a more acidic environment.

\section{References}

[1] J. P. Arnold, Origin and History of Beer and Brewing from Prehistoric Times to the Beginning of Brewing Science and Technology, Cleveland, Ohio: BeerBooks 2005

[2] M. Nelson, The barbarian's beverage: a history of beer in ancient Europe. (London:Routledge, 2005), 6

[3] G. Rosini, F. Federici, A. E. Vaughn and A. Martini, Systematics of the species of the yeast genus Saccharomyces associated with the fermentation industry. European Journal of Applied Biotechnology, 15, 1982, 188-193

[4] W. D. Klein, M. Lansing and J. Harley, Microbiology, $6^{\text {th }}$ edition (New York: McGraw-Hill)

[5] H. Erten, H. Tanguler and H. Cakiroz, The Effect of Pitching Rate on Fermentation and Flavour Compounds in High Gravity Brewing. Journal of the Institute of Brewing 113(1), 2007, 342

[6] J. H. Munroe, Fermentation in Handbook of Brewing,William A. Hardwick (ed) (New York: Marcel Dekker, 1995)

[7] A. O. Aisien, G. H. Palmer and J. R. Stark, Starch/Starke. 35:316 as cited by N. G. Aniche and N. Okafor, 1989. Studies on the effect of germination time and temperature on malting of rice, Journal of the Institute of Brewing, 95, 1983, $165-167$.

[8] A. O. Aisien and G. C. J. Muts, Micro-scale malting and brewing studies of some sorghum varieties. Journal of the Institute of Brewing, 93, 1987, 328-331

[9] L. Hallgren, Lager beers from sorghum in Dendy, D.A.V. (Ed.), Sorghum and Millets: Chemistry and Technology, American Association of cereal chemists,(St.Paul, MN, USA, 1995), 283-297

[10] W. F. Harrigan and M. E. McCance, Laboratory Methods in Microbiology. (Academic Press, London, New York, 1996)

[11] J. P. Van Der Walt and D.Yarrow, Methods for isolation, maintenance, classification of yeasts, 1984, 45-104.

[12] D. S. Clark, R. H. Wallace and J. J. David, Yeasts occurring on apples and in apple cider. Canadian Journal of Microbiology 1(3), 1954, 145-149.

[13] L. J. Wickerham, Taxonomy of yeast. U.S. Department of Agriculture technical bulletin 1029, $1951,2$.

[14] D. Del pozo-Insfran, D. Urias-Lugo, C. Hermanedez, and S. O.Semasaldivar, Effect of Amyloglucosidase on wort composition and Fermentable carbohydrates Depletion on sorghum lager beers. Journal of the Institute of Brewing 110, 2004,124- 132

[15] Association of Official Analytical Chemists (AOAC) International. 2000. Standard Methods (CD-ROM).

[16] T. Goldammer, Brewer's Handbook, 2nd edition, (Apex, 2008) 181.

[17] R. C Agu, A comparison of maize, sorghum and barley as brewing adjuncts. Journal of the Institute of Brewing, 108,2002, 19-22.

[18] D. NY.Pearson, The Chemical Analysis of Food. (Eddinburgh:Scheckwahtong Printing Press, Churchill Livingstone 1980) $10-12$.

[19] C. Papazian, The complete joy of home brewing. 3rd edition (Harper Collins.New York, 2003)

[20] P. Bernfield, Enzymes of starch degradation and synthesis. Advances in Enzymology 12, 1951, 379-481

[21] European Brewery Convention, Method 8.8.1. Ninhydrin colorimetric method. (international method). Analytica - EBC, $4^{\text {th }}$ Edition, Brauerei- und Getranke-Rundschau, Zurich, 1987, 141

[22] J. S. Hough, Quality Control: An Introduction to Brewing Science and Technology part II.Journal of the Institute of Brewing 91,1980,32-46

[23] A. O. Aisen and B. P. Ghosh, Preliminary studies of the germination behavior of guinea corn (Sorghum vulgare). Journal of Food Science and Agriculture 29(10):1978, 850-852.

[24] D. Reilly, O. Cormac and K. Walsh, K. 2004. Laboratory scale production of high 'gravity wort suitable for broad variety of research application. Journal of the American Society of Brewing Chemists 62(1):200423-2

[25] C. I. Owuama, Brewing Beer with sorghum. Journal of the Institute of Brewing 105, 1999, 23-24.

[26] M. A. Igyor, A. C. Ogbonna and G. H. Palmer, Effect of malting temperature and mashing methods on sorghum wort composition and beer flavour. Process Biochemistry 26, 2001, 1039-1044.

[27] J. S. Hough, D. E. Briggs and R. Slain, Malting and Brewing Science. (Chapman and Hall, London, 1971) 